\title{
Famine As an Instrument of Nazi Occupation Policy in Ukraine, 1941-441
}

\author{
Oleksandr Lysenko \\ Institute of the History of Ukraine, National Academy of Sciences of Ukraine
}

\section{Tetiana Zabolotna}

Institute of the History of Ukraine, National Academy of Sciences of Ukraine

\section{Oleksandr Maievs'kyi}

Institute of the History of Ukraine, National Academy of Sciences of Ukraine

\section{Translated from Ukrainian by Mark Baker}

\begin{abstract}
The article examines a range of questions tied to Nazi Germany's socioeconomic policies in occupied Ukraine during World War II. In line with implementing the General Plan "Ost," the top leadership of the Third Reich intended to cleanse the "eastern territories" of its "superfluous" population for German colonization. As contained in the "Principles of Economic Policy in the East," these directives provided for the physical extermination of tens of millions of people in various ways, as well as the deportation of part of the indigenous population to remote areas. Ukraine's economic exploitation was built in such a way that it doomed the local urban and rural societies to a miserable, half-starved existence. The systematic seizure of food for the needs of the Wehrmacht, the Reich, and its allies made the death of the inhabitants of the occupied lands only a matter of time. The instrumentalization of terror by famine was manifested, on the one hand, by the creation of special structures that requisitioned food resources, and on the other by establishing norms of food supplies that were below the minimal needs for existence. As well, the strict regulation of trade set limits to the sources of food products that could be brought to the cities. This caused mass starvation. The deaths and the diseases that followed created hundreds of thousands of victims among Ukrainians.
\end{abstract}

Keywords: Ukraine, World War II, Nazi occupation policy, famine, survival strategies, morbidity.

\footnotetext{
1 This is a condensed version of the original Ukrainian-language article, authored by Oleksandr Lysenko, Tetiana Zabolotna, and Oleksandr Maievs'kyi, that appeared in the journal Viis'kovo-istorychnyi merydian, vol. 4 (18), 2017, pp. 61-92. It is republished here in translation with permission. Bibliographic references have been reformatted according to MLA, as per EWJUS's style guidelines.
} 
$I^{\prime}$

$\mathbf{n}$ the numerous memoirs of ordinary participants and contemporaries of World War II, memories of famine are among the most difficult experiences described. The war created conditions that allowed for the use of famine as an instrument through which the Wehrmacht and its allies could achieve strategic goals of the eastern campaign. While significant differences of opinion existed among the leaders of the Third Reich on how best to manage the "eastern territories" they planned to conquer, their views concerning the concept of developing "Lebensraum" basically concurred. This vision was most clearly outlined by Adolf Hitler, who stated,

We have an obligation to depopulate to the same degree to which we are obliged to worry about the German population. We must develop a technique of depopulation. You ask, what does it mean to depopulate? Do I intend to eliminate whole peoples? Yes, exactly, everything is leading to this. Nature is harsh; thus, we are obliged to be the same. (Rauschning 12930).

In the process of realizing the sinister general plan "Ost," the Nazi leaders intended to resettle and eliminate 31 million inhabitants of Poland and the western regions of the USSR, where 65 percent of the Ukrainians, 75 percent of the Belarusians, and 80-85 percent of the Poles lived. There were proposals to increase to 51 million those from the native population to be removed in order to quicken the tempo of colonization from thirty to ten years.

On 17 October 1941, during a meeting with Reich Minister of Armaments and Munitions Fritz Todt and Gauleiter Fritz Sauckel, the Führer stressed the necessity of determining the responsibilities of the Reich Minister for the Occupied Eastern Territories, Alfred Rosenberg. Rosenberg's task "would be to push the Slavs, gathered on reservations, as quickly as possible to such a state where they would either abandon their fatherland or die" (Kosyk 537).

Commenting on his "Principles of Economic Policy in the East" (2 May 1941), Hermann Goering noted, "without a doubt, tens of millions of people will perish from hunger when we take all that we need" (Istoriia Ukrains'koi RSR 136). The Reich Marshal considered the food problem easy to overcome with the help of cabbage and turnips. Whoever refused to work would be deprived of all food, and the stubborn ones would be shot on the spot.

"The Directives on Economic Policy for Organizing the Economy in the East," included the following instructions:

The isolation of the black-earth regions will ensure for us in any circumstances the availability of more or less significant surpluses in those regions. As a result-the cessation of supply for the whole forest zone, including large industrial centres (Moscow and Petersburg) .... the German 
administration in this region must make every effort to mitigate the consequences of famine, which undoubtedly will break out and accelerate the process of naturalization. It is necessary to strive for the more intensive agricultural development of these regions, for example, by expanding sown areas of potatoes and other important, useful, high-yielding crops. But famine ultimately cannot be avoided. Several tens of millions of people in this territory will become superfluous and die or will be forced to resettle to Siberia. Attempts to save this population from starvation by sending surpluses from the Black Earth zone could be made only at the cost of the deterioration of the European food supply. They could undermine the capacity of Germany to sustain itself in the war and weaken the blockade strength of Germany and Europe. (Sukharev 435)

Pre-war Germany experienced a substantial shortage of agricultural products, and domestic production did not cover the food requirements of the population. In wartime conditions, the situation was further complicated as previously established trade connections with other states were severed; also, agriculture lost large numbers of workers to mobilization while receiving fewer machines and work tools. The leadership of the Third Reich sought to make up for the deficit in food products at the expense of the occupied, dependent, and "neutral" countries of Western Europe and the newly occupied territories of eastern Europe. Ukraine, with its agricultural potential, was given a leading role. Nazi officials planned to export to Germany from the south and southwestern Soviet Union (that is, Ukraine) all food products and raw materials that they considered "in excess amounts." For the local producers of these products and raw materials, they planned to leave less than the minimum necessary to sustain this population. The Nazis established the following hierarchy for the distribution of food products: "1) for the active army; 2) for the rest of the troops on hostile territory; 3) for troops located in Germany; 4) for the German civilian population; and, in the last instance, for the population of the occupied countries" (Perekhrest 173). Ukraine was also viewed as a market for manufactured goods of western European industry that were to be paid for in agricultural products and raw materials.

An analysis of the directives and orders of the Reich ministries, in particular, of Herbert Backe's Ministry for Food and Agriculture (1942-45), shows that in the occupied eastern territories the organization of a massive famine was foreseen, one that would lead to maximal destruction of the urban and village populations of the region and open up limitless possibilities for German colonization of Ukrainian lands.

The preconditions for famine had been created well in advance. The systematic evacuation measures of the Soviet authorities, implemented in line with a "scorched earth" strategy, had led to the removal of reserves of food products and raw materials, forage for livestock, and the livestock 
themselves from territory threatened with German occupation. All that could not be evacuated to the eastern regions was ordered destroyed or ruined by burning, soaking with water, gasoline, etc. Any reserves of food products (cellars, stores, bases) that remained after the Red Army's retreat were taken by the local population, which anticipated the onset of difficult times. The savviest managed to accumulate significant stores of valuables. However, the majority were unable to create reserves for a "rainy day."

Already in the summer of 1941, difficulties with food supplies were evident, even in areas near the front and under Soviet administrative control. For example, on 15 August 1941, the People's Commissar of Internal Affairs of the UkrSSR, V. Serhiienko, reported to the leader of the NKVD, Lavrentii Beria, and the secretary of the Central Committee of the Communist Party (B) of Ukraine, Nikita Khrushchev, that the food supply situation for inhabitants of Kyiv was in a clearly unsatisfactory state. According to preliminary estimates, the city had available fats and sugar for only two days. The situation with delivery of meat and vegetables to the city was particularly bad. Over the previous five days, no meat at all had been delivered to trade organizations. The actions of the director of a nearby state farm (State Farm No. 8), Tikhonov, had negatively affected the vegetable supply for Kyivites: he had ordered the destruction of a whole store of vegetables - trampled and flooded with water from the irrigation system. Stocks of flour for the capital barely reached ten tons, and deliveries from the periphery had become irregular. Eating establishments had not received produce for five days and their stocks were rapidly vanishing. The author of the report stated that there were two main causes of the extremely unsatisfactory situation: a sharp reduction in the delivery of food products and the desertion of many leaders of the trade network, the communal eateries, and delivery systems (altogether 250 persons). Those fleeing often took state monetary resources with them. ${ }^{2}$

From the first days of the occupation, the "new" authorities introduced their own order and legal norms. The initial measures were aimed at subduing the local population and ensuring a comfortable stay for the functionaries of the occupying authorities and officers and soldiers of the Wehrmacht. Representatives of the German occupation organs demanded the return of anything the population had "illegally" appropriated. Severe punishments were to be applied for violations, as announced in periodicals of Kirovohrad (now Kropyvnytskyi), Dnipropetrovsk (now Dnipro), and Zaporizhzhia ("Vid mis'koi upravy"; "Obov'iazkova postanova;" "Rozporiadzhennia").

2 Haluzevyi derzhavnyi arkhiv Sluzhby bezpeky Ukrainy (hereafter HDA SBU), fond 16 , opys 34 (1951), sprava 2, arkush 82-88. 
While confiscating looted goods, the authorities would quite frequently take personal food stocks as well. Severe limits on food reserves were established; anything that exceeded them was subject to requisition. For example, on 16 December 1941, the command of the German army in Crimea issued an order to the population of Symferopil that surpluses of food products were to be taken to the city government's warehouses (the territory of Crimea until 1954 was part of the Russian Soviet Federative Socialist Republic [RSFSR]). A representative of the authorities explained these measures as necessary to address the hunger, which threatened the population that had no food reserves ("K prikazu o sdache" 2). Subsequently, the military commandant of Symferopil issued a demand that before the end of 1941 all citizens surrender product surpluses in excess of forty kilos of grain or flour, two kilos of fat, and two kilos of sugar per person (Pashchenia 83). In Artem district, people were allowed to keep fifty kilos of grain and thirty-five kilos of flour per family member ("Ob"iavlenie" 2). That these limitation orders were issued throughout the whole period of occupation suggests the population was sabotaging the authorities' explicit decisions. No doubt with their earlier experience of famine in 1932-33 in mind, the population, especially the peasants, strove by any means to hide food products. However, the threat of punishment forced the population under occupation to act carefully. Whoever did not manage to keep some food, would soon experience hunger. The situation was even worse in the cities where the absence of foodstuffs in trade networks meant that people were not able to stock up. However, even in the countryside the situation became more difficult in connection with requisitioning introduced by the occupying organs. For the needs of the German armed forces, they seized cattle, horses, pigs, poultry, and animal products from the village inhabitants (Marchenko 11).

German military and civilian leaders were well aware that such measures would induce famine. The Commander of the Eleventh Army, Erich von Manstein, in an order from 20 November 1941, emphasized the necessity of exporting the maximum amount of agricultural products to the homeland, while foreseeing that in the cities a significant portion of the local population would go hungry (Nuremberg 641). The German administration gave certain privileges (especially in the provisioning of food) to Russian Cossacks on occupied territories of the RSFSR. Cossacks that served in the occupation structures and armed forces received tax benefits and were given additional grants of lands and draught animals (Kadyrov 190). Support of the population in occupied Belarus had its own specifics. The "General political-economic directives for the economic organization 'East,"' issued 23 May 1941, stated that Belarus, which was part of the "forest zone," was to 
provide "significant meat deliveries." 3 At the same time, the territory of Belarus was to be treated separately from the black earth zone, where there were "surplus products." The foreseen deficit of food products in Belarus, however, did not mean that the products would be supplied from the blackearth districts or from Germany itself. Thus, even here the program of supplying the population of the Reich and the Wehrmacht doomed millions of local inhabitants to hunger (Novikov 51-52).

From other documents, it becomes clear that the Nazis' food supply policy was oriented toward solving a pre-war task: a) obtaining reliable sources of food supplies for Germany; and b) depopulating the future "Lebensraum." A report by the inspector of armaments in Ukraine (2 December 1941) included a list of actions necessary to ensure the Reich an uninterrupted supply of food. The decisive measure was the reduction of the internal consumption of the "natives" to a bare minimum through the following steps: a) the elimination of surplus eaters-Jews, inhabitants of large cities; b) a maximal reduction of the food ration norms of the local population; c) reduction of the food supplied to the rural population (Sorokin 179).

The occupying authorities had no single system for supplying food products to the civilian inhabitants of the occupied territories. In any event, the complex food supply situation negatively influenced the attitude of the local population toward the Nazi occupants, raising the threat of the emergence and/or activization of a passive or active resistance movement. Given this "mine of slow-motion activity," the occupation organs developed plans, and local military and civilian authorities addressed this problem, depending on the specific situation. However, measures were largely in the form of propaganda rather than improvements in food security. The local press played a special role in propaganda. Newspapers included pieces informing readers about the organization of special communal dining outlets and on procedures for issuing food ration coupons and the provisioning of products to certain entitled categories of the population (orphans, invalids, pensioners, families of those repressed by the Soviet regime).

The local administration's active measures in this sphere were announced in the press. For example, as early as 7 October 1941, the Kyiv press published an image of the bread ration card that building administrations and building owners were to issue to each family ("Oholoshennia" 4). However, there was no mention of what the norms of provision through the cards would be, or that bread would not be distributed for weeks. We know from the diary of a Kyivite, I. Khoroshunova, that she first used ration cards to obtain bread on 10 October 1941 (the Germans had

3 See "Wirtschaftspolitische Richtlinien für die Wirtschaftsorganisation Ost von 23.5.41., erarbeinet von der Gruppe Landwirtschaft" in Ferchl 65-66. 
arrived in Kyiv on 19 September). The initial norm was 200 grams per person, regardless of whether or not she worked. "Eleven streets are assigned to each store. So the queues begin from early morning. And many go without bread. And the bread for that day disappears" (Khoroshunova; entry from 11 Oct. 1941). Herring was offered for sale twice, sold in allotments of a half-kilo per person. "Get Stalin's [herring], while it is still available, for we won't get a taste of Hitler's [herring] for some time to come," Kyivites sadly joked (Vrons'ka 281). By mid-October 1941 the reserves of bread had been exhausted. Khoroshunova commented: "A real famine has begun here. There is no bread .... It's been impossible to buy anything. All the stores are closed. And now at the markets peasants exchange produce for completely new things only." Further, she noted, "It turns out that one hundred grams of bread is a huge portion. They last gave us bread, two hundred grams each, on the thirtieth [of October 1941]. They promised [more bread] on the fifth [of November], but they did not give it" (Khoroshunova; entries from 17 Oct. and 8 Nov. 1941). The next time Kyivites received this critical product was on 16 and 30 November. In December, bread was also distributed only twice, and this concluded the deliveries for 1941 (Vrons'ka 281). Thus, the rations provided were miserly, and depended on the region, the time of year, and the category of ration card. While in Sumy region and in "Transnistria" the daily ration for working people was 200 grams of bread daily, and in Kirovohrad-400 grams, dependents were not entitled to receive anything; in Kyiv, however, this category of the population could count on receiving 200 grams of bread per week, that is, about 29 grams per day (Tarnavs'kyi 301).

Taking into account German occupation laws on food supply and the limited resources available, local governments strove to improve the situation of city dwellers by establishing norms of food supply. Thus, the Kyiv city administration in April 1942 issued the instruction "On the procedure for issuing food ration cards to the population of Kyiv and with them implementing control over the distribution of food products." According to this document, food ration cards were to be issued to

a) working men; b) unemployed men; c) dependents of the mentioned persons-women and boys up to age 16; d) invalids and pensioners; e) pupils and students who were studying at the time of issue of the cards; f) female housekeepers and dependent women, regardless of age; g) families of individuals repressed or deported by the Bolsheviks from Kyiv; $h$ ) women and children of POWs; i) artisans and private traders with licences at the time of registration; $\mathrm{j}$ ) individuals of the free professions (doctors, lawyers, and others); k) workers and employees who work outside Kyiv and come to the city on business or vacation for more than two weeks; l) families of the sick or those staying for in-patient treatment; $\mathrm{m}$ ) individuals evacuated from other locations whose periods of stay in Kyiv are 
determined to be more than two weeks; and n) children staying permanently in homes for children. ${ }^{4}$

Four categories of consumers were established for the ration cards: the first included invalids, pensioners, private traders, and members of the free professions; to the second belonged dependents of working people and the families of those who had left to work in Germany; to the third belonged those working full time at enterprises and institutions; and to the fourth belonged Volksdeutsch and workers in demanding jobs (at facilities producing weapons, on railroads, in mineral mining, and so on). ${ }^{5}$

The situation with bread supplies stabilized more or less only in the second half of 1942, once the harvest came in: the average weekly bread ration, even for dependents, rose to 1,500 grams. This increase, however, coincided with a significant decrease in the quality of bread, which was confirmed by the spike in the number of people who became sick from eating products with various inedible admixtures. ${ }^{6}$ The hungry inhabitants of the large Ukrainian urbanized centres were forced to add to their diets unsuitable items: oilcake, bran, frozen potatoes, beets, potato skins, meat from dead horses, pets, and even casein glue, as was recorded in Kramatorsk and Kharkiv.

Socially unprotected categories (children, the disabled, the elderly) constantly suffered from hunger. The local authorities organized cafeterias, where a small portion of the needy could suppress the feeling of hunger for several hours with a thin soup, sometimes with a slice of bread. The average cost of lunch in these special public eateries was 1.1-1.7 rubles. Of course, the number of lunches at that subsidized price was limited because the cafeterias did not receive expected funds from the administrations. District departments referred to the fact that they did not have the necessary funds and could cover only part of the expenses.

The local authorities were not successful in addressing the food shortages. They did not, after all, have their own food reserves. The only remaining option was to haul in food products from the villages. However, the absence of means of transportation and fuel hindered this simplest way to solve the food problem, and the newly established co-operatives and consumer associations gradually transformed into conduits for enriching their founders.

\footnotetext{
${ }^{4}$ Tsentral'nyi derzhavnyi arkhiv vyshchykh orhaniv Ukrainy (hereafter: TsDAV0), f. 3676 , op. 4 , spr. 475 , ark. 460.

${ }^{5}$ Derzhavnyi arkhiv Kyivs'koi oblasti (hereafter: DAKO), f. R-2356, op. 5, spr. 13, ark. $62,63$.

6 TsDAVO, f. 3676, op. 4, spr. 475, ark 43.
} 
Townspeople, attempting to solve the difficult food problem themselves, hiked to nearby and distant villages to exchange industrial goods for food. Throughout the Nazi occupation, street markets were important sources, although the occupation authorities restricted food imports, introduced "firm prices," fought the "bagmen," and even banned the street market trade, which left many people during the winters of 1941-42 and 1942-43 on the verge of death by starvation. The shortage of food products and the spread of the "black market" caused speculation, inflation, and a surge in prices at the markets. In Kharkiv during the summer of 1942, one kilo of bread cost 150 rubles, while the officially set price was 1.7 rubles; one egg cost 8 rubles (officially, $0.80 \mathrm{rub}$ ); one litre of milk -20 rubles (1.2 rub.), one litre of sunflower oil -280 rubles ( 14.5 rubles), butter -600 rubles, one kilogram of backfat $-1,000$ rubles, one kilogram of wheat bread -50 rubles, rye -35 rubles, one kilo of sugar -500 rubles (Pashchenia 86 ).

The low purchasing power of the local population was determined by extremely low wages in comparison with prices. In the territory of the Reichskomissariat Ukraine, a worker earned 400 rubles per month, an accountant -500 rubles, a typist -400 rubles, managers of various levelsfrom 900 to 1,500 rubles. In the summer of 1942, the salary of the average white-collar employee was 700-800 rubles, at a time when one kilo of backfat cost 750 rubles. By March 1943, one kilo of this product could be bought for six thousand rubles, while salaries remained the same (Spudka 13).

Neither the personal efforts of the urban population nor the actions of the local occupation authorities could prevent the onset of starvation. In early March 1942, Joseph Goebbels noted in his diary: "The situation with food supply in the occupied eastern regions is extremely difficult. There, thousands and tens of thousands of people are dying from hunger, which does not interest anyone at all" (Miuller 132).

Nazi policies that induced the famine also led to the eating of corpses and cannibalism. According to Oleksandr Symonov, a professor of fine arts from Kharkiv, the Germans hanged those accused of cannibalism with a sign on their chests: "I was hanged for selling human meat" (Skorobahatov 278). According to some sources, in the summer of 1942, at the street market in "Kinna Ploshcha" (Equestrian Square) in Kharkiv, a man was hanged for selling a liver and lungs of people who had died of hunger (Skorobahatov 278). In Kyiv, there were rumours that in the Podil neighbourhood a group had been uncovered that was killing people and selling their meat. There were other cases of killing for this purpose. All the same, the official press reported only one act of cannibalism, when a fifty-year-old man named Korniienko ate a sixteen-year-old girl. As a result, Korniienko was publicly hanged on 27 January 1943 in the centre of Kyiv (Berkhoff 181). 
Nazi policies and practices also led to mass diseases associated with systematic malnutrition-hypertrophy, dystrophy, rickets, nephritis, scurvy, tuberculosis, measles, scarlet fever, diphtheria, whooping coughand death from these diseases. From the arrival of the German troops in Kyiv (19 September 1941) to 1 April 1942, about eight thousand of the city's inhabitants died of hunger, cold, and illnesses caused by them (Malakov). According to data from the Kharkiv city administration, as presented by A. Skorobahatov, in 1942 (more exactly, from the second half of December 1941 to the first half of December 1942), 13,139 people of Kharkiv starved to death, accounting for 58.4 percent of all deaths in that period. Even this unprecedented high percentage of deaths from hunger was likely higher still: according to the head of the department of Kharkiv's city administration, Professor Ie. Ie. Dobrovol's'kyi, some doctors filled out the "doctor's reports" about the death of citizens incorrectly, avoiding the diagnosis of "death from hunger," replacing it with other causes, such as "edema from insufficient protein," "paralysis of the heart," "child frailty," and others (Skorobahatov 279). Thus, as in Soviet times, the truth was concealed; the "new" authorities avoided the disclosure of information about the terrible consequences of its rule for the local population, giving preference to self-congratulatory, optimistic newspaper articles with a perceptible, propagandistic "spirit." Timothy Snyder, speaking about the commonalities of the two totalitarian regimes, asserts, "in light of the scarcities, particularly of food supplies, both regimes integrated mass murder with economic planning" (16).

The food supply situation in the occupied settlements of Ukraine remained difficult throughout the entire stay of the German authorities and troops in the captured territories and for long after. The actions of local authorities in this area as reported in the newspapers seemed rather effective and active, but, in fact, they mostly had a declarative character. In fact, the population was compelled to save itself from death by starvation. And the delivery norms anticipated by the local authorities, based on the food ration cards, were so paltry as to look more like mockery than help.

The course taken to organize an artificial famine was a component of German agrarian policy. As planned, large cities were not sufficiently provided with food. People starved who did not have work or social connections with the village, especially in the winter. This was primarily the case in Kyiv, the Donbas, the Crimea, and northeastern Ukraine. The Kharkiv region was declared a zone of "total requisitioning" (in German: "Kahlfraßzone," literally where "absolutely everything is eaten"), in which the Wehrmacht divisions obtained food at their own discretion. The consequences were disastrous for the local population (Pol'), who were offered trips to Germany, where the Ostarbeiter would supposedly be 
ensured a pleasant living situation and nourishment ("Pratsia v Nimechchyni").

Although the policy of forced removal of working people from the occupied territories to contribute to the Third Reich economy was framed in terms of their rational use and preservation, in practice it was often otherwise. Already during the transportation stage, Ostarbeiters were subjected to starvation. Paraskeviia Kyslenko, a resident of the town of Ladan (Pryluky district), recalled that she was first taken away with others from her village in a closed train car to Kyiv; there they stayed in a camp; they were then sent to Magdeburg in closed train cars. During this exhausting trip, they were given food only once. Vasyl' Nalyvaika, a resident of the village of Andriivka (Mykhailo-Kotsiubynskyi district), recalled: "We travelled in a closed train car under guard. They gave us nothing to eat." A native of the village of Ivankivtsi, Ol'ha Berezhna, who was taken to Germany as a sixteen-year-old because her father was a party member, wrote, "We travelled for a month; there was nothing to eat; they only gave us boiling water" (Nesterenko 155). Kateryna Kashka from Chernihiv region recalled the following:

They brought us to a concentration camp. Each morning they gave us bread with sawdust (only 100 grams per day) and margarine (5 grams each). And for lunch there was some sort of brew made from moldy biscuits-it would hang down from the ladle, when it was poured onto the plates. No matter how hungry I was, I could not swallow even a spoonful! Well, I thought, I'll die, what can you do? ... For two weeks we were kept in that camp. Then, they took us to the bathhouse, but people were so exhausted that some did not make it there. All were emaciated, skinny, like living skeletons. (Nesterenko 157).

The press of the occupation authorities gave the opposite impression. Indeed, it was reported in these newspapers that the future workers of the Third Reich were provided with food in transit, and there were descriptions of the pleasant living conditions in Germany. And the trip abroad was generally viewed as a chance to change one's life for the better: to see the world, to gain a profession, to experience life in a cultured environment, and so on. Especially persuasive for the population were letters from the Ostarbeiters published in the periodicals. ${ }^{7}$

\footnotetext{
${ }^{7}$ Holos Volyni, 21 Feb. 1942, p. 2; Nove ukrains'ke slovo, 26 April 1942, p. 3; Volyn', 14 May 1942, p. 2; Volyn', 17 May 1942, p. 2; Volyn', 21 May 1942, p. 2; Nove ukrains'ke slovo, 13 June 1942, p. 4; Uriadovi Dunaievets'ki visti, 14 June 1942, p. 3; Nove ukrains'ke slovo, 19 July 1942, p. 4; Vasyl'kivs'ki visti, 26 July 1942, p. 3; Dniprova khvylia, 26 Sept. 1942, p. 3; Olevs'ki visti, 4 Oct. 1942, p. 4; Volyn', 12 Nov. 1942, p. 3; Volyn', 15 Aug. 1943, p. 4; Volyn', 19 Aug. 1943, p. 4; Volyn', 26 Aug. 1943, p. 4;
} 
A rather common practice for distracting the local population from the problems of daily life was the publication of articles on the Famine of 193233 ("Ugroza goloda V SSSR;" "Do statystyky holodu"). One of these publications included vivid statistical data that underscored Soviet crimes ("Do statystyky holodu"). Such articles were intended to increase the hatred of the local population toward Soviet rule and to divert people's attention from the problems of the present to the horrific times of the past. In addition, the occupation press contained reports on the difficult food situation in the Soviet Union. 8

Thus, the Nazi leaders and the occupation administration created a contradictory situation, which they were not able to overcome. The first dichotomy was that while the Reich truly needed a healthy workforce, economizing had a detrimental effect on the working capabilities of the inhabitants of the occupied territories, prisoners of war, and Ukrainian Ostarbeiters. The second dichotomy was between Germany's growing needs for agricultural raw materials and products, on the one hand, and the reduction of these resources in the occupied lands, on the other. The methods chosen by the Nazi authorities to conquer and subjugate Ukraine determined the collapse of Berlin's occupation policy and caused enormous demographic losses among the inhabitants in the occupied territories and their descendants.

Ukrains'kyi holos (Proskuriv), 16 Sept. 1943, p. 4; Olevs'ki visti, 15 Aug. 1943, p. 4; and others.

8 "Prodovol'che postachannia naselennia SSSR pid chas viiny," Nove ukrains'ke slovo, no. 234 (249), 8 Oct. 1942, p. 3; "Golod v Kuibysheve," Donetskii vestnik, 24 Feb. 1943, p. 2; "Tsar'-golod v SSSR," Molva, 30 Sept. 1943, p. 1; "Predstoit zima poval'nogo goloda," Nash put' (Kherson), 8 Aug. 1943, p. 3; "Holod u bil'shovykiv," Dnipropetrovs'ka hazeta, 9 Feb. 1943, p. 2; "Golod nastupaet," Poslednie novosti, 26 Jan. 1942, p. 1; "SSSR nakanune goloda," Golos pravdy, 4 Feb. 1944, p. 6. 


\section{Works Cited}

Berkhoff, Karel C. Harvest of Despair: Life and Death in Ukraine under Nazi Rule. Harvard UP, 2004.

"Do statystyky holodu." Donetskii vestnik, 11 Dec. 1942, p. 4.

"Do statystyky holodu v Ukraini." Nova Ukraina, 11 May 1943, p. 3.

Ferchl, Irene Philipp. Verbrechen der Wehrmacht: Dimensionen des Vernichtungskrieges 1941-1944: Ausstellungskatalog. Hamburger Institut für Sozialforschung, Hamburger Edition, 2002.

Istoriia Ukrains'koi RSR u 8 t. 10 kn. Vol. 7, Naukova Dumka, 1977.

Kadyrov, B. G. "Nemetsko-fashistskaia okkupatsiia sovetskikh territorii v 1941-1943 gg." Aktual'nye problemy ekonomiki i prava, no. 2, 2007, pp. 188-92.

Khoroshunova, Irina A. "Pervyi god voiny." Al'manakh "Iehupets'," no. 9, Aug. 2013, pp. 45-46, 51, https://gordonua.com/specprojects/khoroshunova2.html. Accessed 22 Jan. 2019.

Kosyk, Volodymyr. Ukraina i Nimechchyna u Druhii svitovii viini. Naukove tovarystvo imeni T. Shevchenka u L'vovi, 1993.

"K prikazu o sdache izlishkov produktov." Golos Kryma, 21 Dec. 1941, p. 2.

Malakov, D. "Nezabutnie mynule Kyieva-u fotoal'bomi 'Kyiv 1939-1945.'” Dzerkalo tyzhnia, 4-10 Feb. 2006, https://dt.ua/SOCIETY/nezabutne_minule_kieva_u_fotoalbomi_kiyiv_193919 45.html. Accessed 13 Dec. 2018.

Marchenko, V. A. Rozsekrecheni dokumenty period natsysts'koi okupatsii Sums'koi oblasti 1941-1943 rokiv (Ohliad dokumentiv). Derzhavnyi arkhiv Sums'koi oblasti, 2003.

Miuller, N. Vermakht i okkupatsii (1941-1944). O roli Vermakhta $i$ ego rukovodiashchikh organov $v$ osushchestvlenii okkupatsionnogo rezhima na sovetskoi territorii. Voenizdat, 1974.

Nesterenko, L. "Ostarbaitery Chernihivshchyny: verbuvannia, umovy pratsi na chuzhyni ta zhyttia pislia povernennia." Ukrains'ka Druha svitova: Materialy mizhnarodnoi naukovoi konferentsii do 70-i richnytsi peremohy nad natsyzmom $u$ Druhii svitovii viini (5 travnia 2015 r., m. Kyiv), K. I. S., 2015, pp. 153-61.

Novikov, S. E. "Germanskaia okkupatsionnaia politika na okupirovannoi territorii Belarusi (1941-1944)." Rossiiskie i slavianskie issledovaniia: nauch. sb., no. 2, Belorusskii gosudarstvennyi universitet, 2007, pp. 51-63.

Nuremberg Trial Proceedings. Vol. 20, William S. Hein, 1947, http://avalon.law.yale.edu/imt/08-10-46.asp. Accessed 8 Feb. 2021.

“Ob"iavlenie." Bakhmutskii vestnik, 25 Feb. 1942, p. 2.

"Obov"'iazkova postanova Dnipropetrovs'koi mis'koi upravy." Dnipropetrovs'ka hazeta, 1 Nov. 1941, p. 2.

“Oholoshennia." Ukrains'ke slovo, 7 Oct. 1941, p. 4.

Pashchenia, V. N. "'Novyi poriadok' na okkupirovannoi territorii Krymskoi ASSR v 1941-1944 gg. i tatarskii vopros.” Kul'tura narodov Prichernomor'ia, no. 79, 2006, pp. 82-88.

Perekhrest, 0. H. "Sil's'kohospodars'kyi potentsial Ukrainy v heostratehichnykh ta voiennykh planakh natsysts'koi Nimechchyny." Storinky voiennoi istorii Ukrainy, vol. 13, 2010, pp. 170-74. 
Pol', Diter (Dieter Pohl). "Nimets'ka okupatsiina polityka Ukrainy 1941-1944 u konteksti podii Druhoi svitovoi viiny." Histor!ans, 19 June 2015, http://www.historians.in.ua/index.php/en/doslidzhennya/1547-diter-polnimetska-okupatsiia-ukrainy-1941-1944-u-konteksti-podii-druhoi-svitovoiviiny. Accessed 13 Dec. 2018.

"Pratsia v Nimechchyni." Kam"ians'ki visti, 1 June 1943, p. 1.

Rauschning, Hermann. Gespräche mit Hitler. Europa Verlag, 1940.

"Rozporiadzhennia." Nove Zaporizhzhia, no. 12, 21 Dec. 1941, p. 3.

Skorobahatov, A. V. Kharkiv u chasy nimets'koi okupatsii (1941-1944). Prapor, 2004.

Snaider, Timoti (Timothy Snyder). "Znekhtuvana diisnist' Holokostu." Krytyka, no. 910 (143-144), Sept.-Oct. 2009, pp. 14-16. Translation of Timothy Snyder, "Holocaust: The Ignored Reality," New York Review of Books, vol. 56, no. 12, 2009. https://www.nybooks.com/articles/2009/07/16/holocaust-the-ignoredreality/. Accessed 8 Feb. 2021.

Sorokin, G. M., et al. "Nemetsko-fashistskaia sistema ogrableniia i ekonomicheskoi ekspluatatsii okkupirovannykh territorii SSSR." Nemetsko-fashistskii okkupatsionnyi rezhim (1941-1944): Sbornik statei, edited by E. A. Boltin, Politizdat, 1965, pp. 151-186.

Spudka, I. M. "Nimets'ka okupatsiina polityka u sotsiokul'turnii sferi v reikhskomisariati 'Ukraina.'” 2007. Zaporiz'kyi natsional'nyi universytet, $\mathrm{PhD}$ dissertation (Avtoreferat dys. na zdobuttia nauk. stupenia kand. ist. nauk).

Sukharev, A. Ia, editor. Niurnbergskii protsess: Sbornik materialov. Iuridicheskaia Literatura, vol. 1, 1978. 8 vols.

Tarnavs'kyi, I. S. Polityka Tret'oho Reikhu ta ioho soiuznykiv na okupovanykh ukrains'kykh zemliakh v roky Druhoi svitovoi viiny. TOV “VPP 'Promin','” 2012.

"Ugroza goloda v SSSR." Odesskaia gazeta, 23 July 1942, p. 2.

"Vid mis'koi upravy." Ukrains'kyi holos, 15 Oct. 1941, p. 4.

Vrons'ka, T. V., et al., editors. Kyiv u dni natsysts'koi navaly: Za dokumentamy radians'kykh spetssluzhb. Instytut istorii Ukrainy, 2003. 